\title{
Root biomass and biomass increment in a beech (Fagus sylvatica L.) stand in North-East France
}

\author{
Noël Le Goff* and Jean-Marc Ottorini \\ UMR INRA-ENGREF «Ressources Forêt-Bois», \\ Équipe «Croissance et production», 54280 Champenoux, France
}

(Received 19 November 1999; accepted 13 June 2000)

\begin{abstract}
This study is part of a larger project aimed at quantifying the biomass and biomass increment of an experimental beech stand aged 30 years, and comparing the carbon sequestration in trees to carbon fluxes. The below ground part of trees is expected to play an important role in carbon sequestration. A method has been developed to estimate the biomass and biomass increment of coarse, small and fine roots of trees from root system excavations of sampled trees of different crown classes. The biomass and biomass increment of broken root ends during excavation was estimated from the diameter of the roots at the broken points. Equations were then established relating the biomass and biomass increment of the different root categories to tree DBH. These equations were then used to estimate the root biomass and biomass increment of the experimental stand from stem inventory, for the different root categories. Trees from dominant and codominant crown classes contribute for more than $80 \%$ to below ground biomass and biomass increment of the stand.
\end{abstract}

root system / biomass / biomass increment / biomass distribution / Fagus sylvatica

Résumé - Biomasse et accroissement en biomasse du système racinaire dans un peuplement de hêtre du Nord-Est de la France. Cette étude fait partie d'un projet plus vaste ayant pour objectif l'estimation de la biomasse aérienne et souterraine d'un peuplement expérimental de hêtre de 30 ans et de son accroissement, pour comparer la quantité de carbone séquestrée annuellement dans les arbres aux flux de carbone mesurés par les échanges gazeux. La partie souterraine des arbres paraît jouer un rôle important dans la séquestration du carbone. Une méthode a été développée pour estimer la biomasse et l'accroissement en biomasse des racines de différentes catégories de grosseur grâce à l'extraction du sol de systèmes racinaires d'un échantillon d'arbres représentatif des différentes classes de statut social du peuplement. La biomasse et l'accroissement en biomasse des parties de racines cassées lors de l'extraction du sol ont pu être estimés, pour chaque catégorie de racine, à partir du diamètre des racines au niveau de la cassure. Des relations ont ensuite été établies entre la biomasse racinaire et son accroissement, pour chaque catégorie de racines, et le diamètre de l'arbre à 1,30 m. Ces équations ont été utilisées pour estimer les biomasses au niveau du peuplement à partir de l'inventaire des arbres. Les arbres dominants et codominants du peuplement contribuent pour plus de $80 \%$ à la biomasse souterraine du peuplement et à son accroissement.

système racinaire / biomasse / accroissement de la biomasse / répartition de la biomasse / Fagus sylvatica

\section{INTRODUCTION}

The potential of trees and forests to sequester carbon is of major concern today in relation to the continuous increase of $\mathrm{CO}_{2}$ in the atmosphere which contributes to the general rise of the world temperature [7]. Several research projects are being conducted to study $\mathrm{CO}_{2}$ fluxes for different forest types around the world [1]. This study is part of a cooperative research project in which measurements of $\mathrm{CO}_{2}$ fluxes at the tree and stand levels

* Correspondence and reprints

Tel. (33) 03833940 41; Fax. (33) 03833940 34; e-mail: le_goff@nancy.inra.fr 
are conducted in a beech stand to investigate the ecophysiological factors governing carbon uptake and growth of trees [24]. Biomass increment estimations are compared with the carbon balance resulting from photosynthesis and respiration processes in a companion paper [17].

Root systems are a major compartment of forest stands in terms of accumulated biomass and yearly biomass increment. Root biomass represents 15 to $20 \%$ of total biomass as estimated for forests in the United States $[6,23]$ and 19 to $36 \%$ of total biomass as revealed by the carbon budget of the Canadian forest sector [23]. Root biomass proportion depends on the species and ecological conditions, but it may also depend on silvicultural treatments and environmental change [22]. Therefore, root biomass and root biomass increment need to be estimated carefully in any attempt to quantify carbon sequestration in trees and to compare the carbon incorporated annually in trees to the carbon balance resulting from ecophysiological processes.

Biomass equations have been established recently for beech [2, 32]. However, these equations only concern the aerial compartments of trees (stem, branches and leaves). This paper presents a set of biomass and biomass increment equations which can be used to estimate the root biomass and root biomass increment of beech trees in the experimental stand under study. These equations are used to estimate the root biomass and the root biomass increment at stand level. The results obtained for the aerial parts of trees in the same stand will be presented in another paper so as to develop here with enough details the methods used for the study of root biomass and biomass increment.

\section{MATERIALS AND METHODS}

\subsection{Study site}

The study was conducted over two years (1996 and $1997)$ in the state forest of Hesse, located in the East of France, about $80 \mathrm{~km}$ east of Nancy $\left(48^{\circ} 40^{\prime} \mathrm{N}, 7^{\circ} 05^{\prime} \mathrm{E}\right.$; altitude $300 \mathrm{~m}$ ). The climate is semi-continental: mean annual temperature averages $9.2{ }^{\circ} \mathrm{C}$ and total annual precipitation averages $820 \mathrm{~mm}$.

The experimental stand -0.6 ha in surface - belongs to a management unit treated as high forest, 30 years old approximately in 1996 (table I). Beech represents about $80 \%$ of the stems of the stand; other tree species represented are hornbeam (Carpinus betulus), silver birch (Betula pendula), sessile oak (Quercus petraea), wild cherry (Prunus avium), ash (Fraxinus excelsior) and European Larch (Larix decidua). The main stand characteristics before 1996 growing season were as follows: the mean stand density is about 3500 stems ha ${ }^{-1}$, corresponding to a basal area of $15.5 \mathrm{~m}^{2} \mathrm{ha}^{-1}$. The mean height and the dominant height of the stand reached respectively 13 and $15 \mathrm{~m}$, while the mean diameter and the dominant diameter of the stand were 7.6 and $15.3 \mathrm{~cm}$ at breast height $(1.30 \mathrm{~m})$ respectively.

The topography of the experimental stand and of the surrounding area is relatively flat with a gentle slope to the south. The parent material is clay or sandstone with a loam layer of varying depth. The soil is covered with a mull-type humus.

\subsection{Stand measurements}

The experimental stand was divided into 60 plots of approximately 0.01 ha. Among these 60 plots, a sample of 12 plots was selected on a regular basis, but avoiding particular areas (a track crossing the stand and parts of the borders). These plots were used to inventory the stand after 1996 and 1997 growing seasons by measuring the girth and height of all the trees of each plot. However, a complete tree girth inventory of all the trees in the experimental stand was also performed before 1996 growing season [24].

The stand structure was characterized with Kraft classification to depict the social status of trees [28]. Four crown classes were recognized in the stand (dominant, codominant, intermediate and suppressed). Examination of trees of each crown class allowed an estimation of the girths corresponding to the lower bounds of the dominant, codominant and intermediate tree classes. On this basis, the inventory of the total stand revealed the following distribution of trees among crown classes [24]: $19.8 \%$ dominant (crown class 1), 33.0\% codominant (crown class 2), $21.0 \%$ intermediate (crown class 3 ) and $30.9 \%$ suppressed (crown class 4 ).

\subsection{Tree sample}

The proportional sampling of each crown class yielded the same number of trees in each of the four crown classes. Following this sampling scheme, 16 trees were selected (11 in 1996 and 5 in 1997) outside the experimental stand but in similar site and stand conditions, equally distributed in each crown class, for a detailed study of the root system (table I). 
Table I. Characteristics of the 4 sampled trees in each crown class (mean and standard deviation $s d$ ).

\begin{tabular}{lcccccc}
\hline $\begin{array}{l}\text { Crown } \\
\text { class* }\end{array}$ & \multicolumn{2}{c}{$\begin{array}{c}\text { Age } \\
\text { (years) }\end{array}$} & \multicolumn{2}{c}{$\begin{array}{c}\text { DBH } \\
(\mathrm{cm})\end{array}$} & \multicolumn{2}{c}{$\begin{array}{c}\text { Height } \\
(\mathrm{m})\end{array}$} \\
\cline { 2 - 8 } & mean & sd & mean & sd & mean & sd \\
\hline 1 & 35 & 7 & 13.9 & 4.4 & 15.1 & 1.4 \\
2 & 31 & 5 & 7.6 & 1.1 & 13.0 & 0.6 \\
3 & 31 & 5 & 5.9 & 0.3 & 11.6 & 0.8 \\
4 & 24 & 3 & 4.0 & 0.8 & 8.7 & 1.0 \\
\hline
\end{tabular}

* Crown class: 1: dominant; 2: codominant; 3: intermediate; 4: suppressed.

\subsection{Root data collection}

The sampled trees were cut at ground level at the end of the growing season for the biomass study of the aerial parts of the trees. In the following spring, the root systems were excavated with a mechanical shovel so as to minimize loss or breakage of roots. Then, the root systems were taken away and left on a lawn near the laboratory where they were washed to remove soil particles and exposed to the open air to dry. Subsequently, root systems were put under cover and placed upside down on a flat surface for measurement processing. Roots were sorted into three size classes (figure 1) depending on the cross-sectional diameter $(d)$ of the roots [22]: coarse roots $(d \geq 5 \mathrm{~mm})$, small roots $(2 \leq d<5 \mathrm{~mm})$ and fine roots $(d<2 \mathrm{~mm})$.

On each root system, samples $10 \mathrm{~cm}$ in length (socalled increment samples) of regular shape, were cut from coarse and small roots to estimate the current annual volume increments and biomass increments of the root systems. One increment sample per root was generally cut, but several could be taken on major roots along the root length. A total of 106 increment samples were analyzed, the number of samples per root system being larger on average for trees of dominant (10 per tree) and codominant crown classes (6 per tree) than for trees of intermediate and suppressed crown classes ( 5 per tree). The length of each root increment sample and their diameters measured along two perpendicular directions through the pith, one being the direction of maximal diameter, were recorded for each end of the increment samples so as to evaluate the volume of the increment sample over bark. The annual cross-sectional increments of both ends were then measured every $45^{\circ}$, starting at the major axis, by using a travelling stage microscope with a $0.1 \mathrm{~mm}$ precision. On each increment sample section, the annual radial increments measured in each direction were synchronized and the geometric mean of annual increments was calculated for each section. Then, the mean annual radial increments of the root samples were cross-dated for each tree by comparing their pattern of variation with that of the annual radial increments measured on the stump section for the study of the aerial part of trees [20]. This allowed calculating the inside bark mean diameter of both sections of the increment samples for the year preceding the current year and the corresponding volume. The inside bark current annual volume increment of the increment samples was then calculated as the difference between the inside bark volumes of the increment samples for the current year and the previous one.

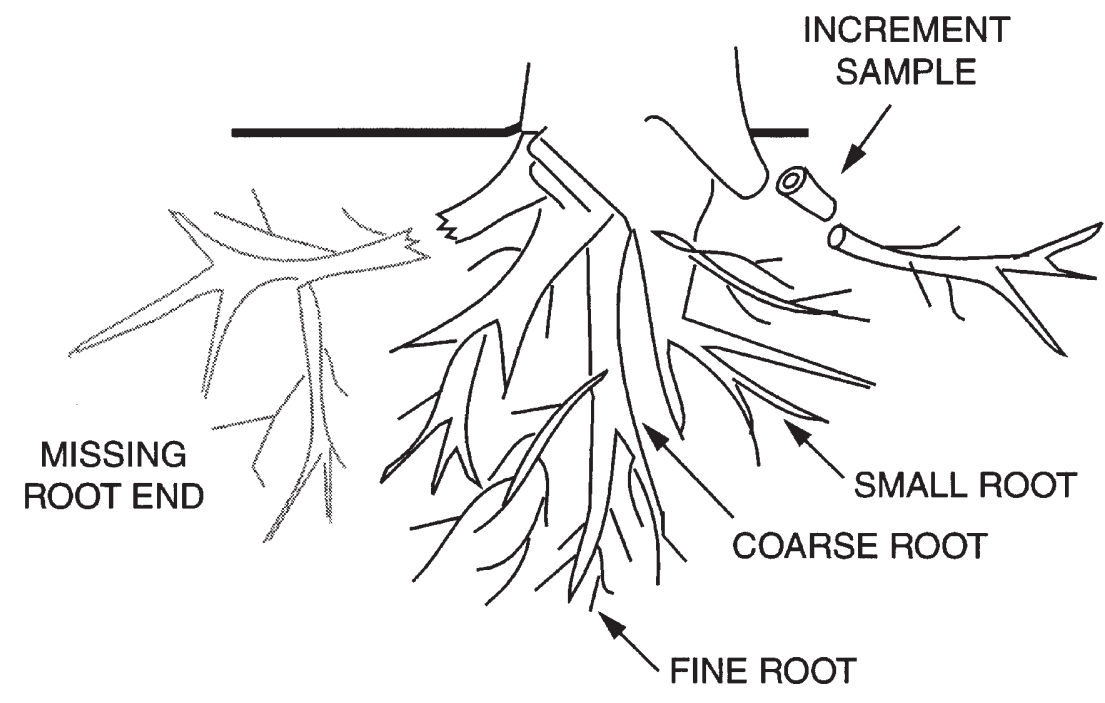

Figure 1. Diagram of a beech root system with roots of various size classes and a missing root end (in gray) whose biomass characteristics are to be estimated. A root increment sample is also shown. 
Although the root systems were excavated with caution, many roots were broken during excavation and remained in the soil. Corrections for this loss of biomass were obtained by tallying the diameters at the broken ends and then applying a regression of root weight on root end diameter to the tally of broken root ends, following the method reported by Santantonio [30]. In addition, specific relations were established to evaluate the contribution of each root category to this missing biomass. The diameters of broken root ends were measured outside bark at the point of breakage, in two perpendicular directions including the major axis. Unbroken root ends were sampled on each root system and cut at one, two or three points so as to obtain unbroken root ends of different diameters from a given sampled root end. For each resulting piece of the unbroken root ends sampled, the two perpendicular diameters at the cut end were measured outside bark, and the roots were sorted into the three size classes defined for biomass measurements.

The root systems were oven-dried to a constant weight at $105{ }^{\circ} \mathrm{C}$, and the dry weight of each root category - coarse, small and fine - was recorded separately for each root system.

The term "biomass" will be used afterwards to refer to the sum of wood dry weight and bark dry weight.

\subsection{Root data processing}

\subsubsection{Biomass equations for missing root ends}

First, a general equation for the roots of the different categories was established with the pooled sample of unbroken root ends, to relate the biomasses of root ends to the diameter at their origin. A linear model was adjusted to root biomass data, after a two-sided logarithmic transformation (table III, figure 2):

$$
\ln (t r b)=3.0096+2.0949 \ln (d)
$$

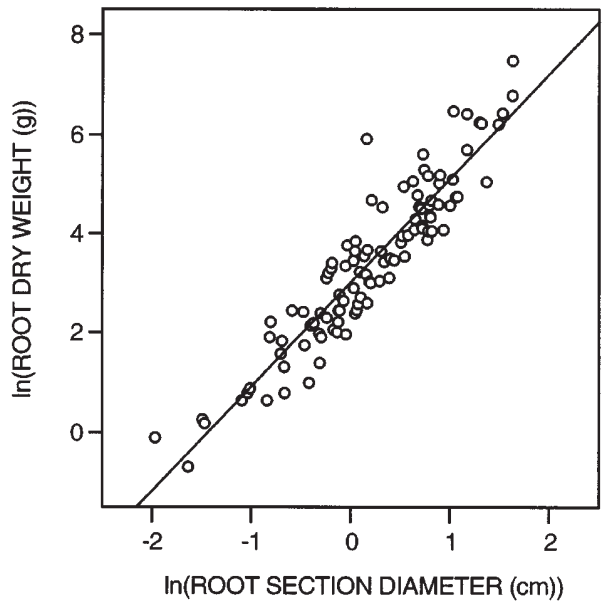

Figure 2. Relationship between the total biomass of a root end and the mean diameter of the cross-section at the base of the root end.

where trb is the total biomass of the root end ( $\mathrm{g}$ ) and $d$ is the mean diameter at the origin of the root end $(\mathrm{cm})$.

Then, for each sample root end, the biomass of each root category was expressed as a fraction of the total root end biomass and related to the diameter $d(\mathrm{~cm})$ of the root end (tables II and III, figure 3).

For each tree root system, the missing biomass was estimated for each root category from the diameter inventory of broken roots with equation (1) and equations (2), (3) and (4) for coarse roots, equation (1) and equations (5) and (6) for small roots and equations (1) and (7) for fine roots. Equation (1) was inversely transformed and the biomass values obtained were multiplied by a factor equal to the exponential of the half mean square error for bias correction [13]. The estimations obtained for missing biomass were added to the biomass quantities measured to obtain the biomass of each root system sampled per root category.

Table II. Equations established for the different biomass fractions of the sample root ends classified in root categories.

\begin{tabular}{lcccc}
\hline Root end category & \multicolumn{3}{c}{ Fractions of total root biomass $(t r b, \mathrm{~g})$} \\
\cline { 2 - 5 } & coarse root biomass $(c r b, \mathrm{~g})$ & small root biomass $(s r b, \mathrm{~g})$ & fine root biomass $(f r b, \mathrm{~g})$ \\
\hline Coarse roots $(d \geq 0.5 \mathrm{~cm})$ & $\frac{c r b}{t r b}=0.91206-\frac{0.36505}{d}$ (2) & $\frac{s r b}{t r b}=0.04543+\frac{0.19979}{d}$ & $(3)$ & $f r b=t r b-(c r b+s r b)$ \\
Small roots $(0.2 \leq d<0.5 \mathrm{~cm})$ & 0 & $\frac{s r b}{t r b}=0.97354-\frac{0.1560}{d}$ & $(5)$ & $f r b=t r b-s r b$ \\
Fine roots $(d<0.2 \mathrm{~cm})$ & 0 & 0 & $f r b=t r b$
\end{tabular}


The biomass estimated for missing root ends of a tree represented about $13 \%$ of the biomass measured for the different root systems excavated, but large variations
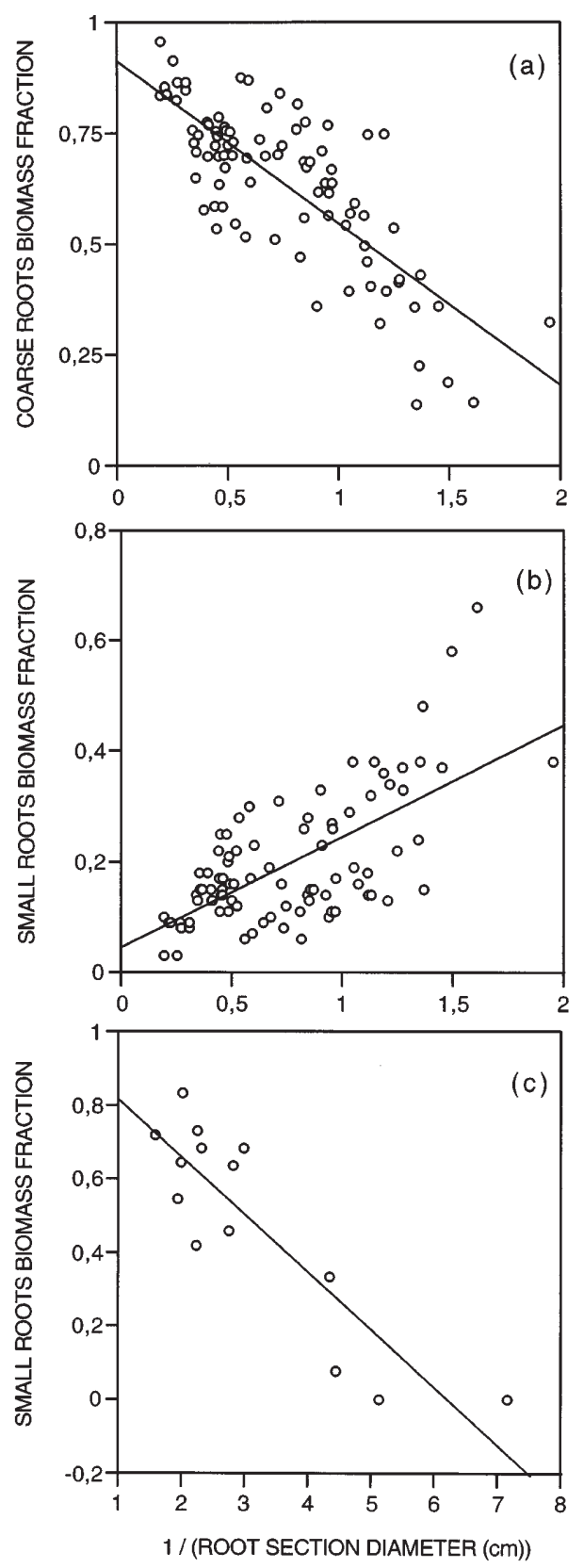

Figure 3. Coarse root biomass fraction (a) and small root biomass fraction (b) in relation to the inverse of the basal diameter of the root end for coarse roots (equations (2) and (3)). Small root biomass fraction (c) in relation to the inverse of the diameter of the root end for small roots (equation (6)). occurred, the percentage varying from 5 to $35 \%$ between trees.

Table III. Statistics of the biomass equations established for sample root ends ( $s e$ : standard error of the predicted values; df: degrees of freedom; $\mathrm{R}^{2}$ : determination coefficient).

\begin{tabular}{lcrc}
\hline Equation & $s e$ & $\mathrm{df}$ & $\mathrm{R}^{2}$ \\
\hline 1 & 0.1580 & 103 & 0.86 \\
2 & 0.1143 & 86 & 0.60 \\
3 & 0.0870 & 86 & 0.44 \\
5 & 0.1442 & 13 & 0.76 \\
\hline
\end{tabular}

\subsubsection{Biomass increment relations}

The relative annual volume increment of root increment samples appeared to be independent of the root cross-sectional area towards the stump side (figure $4 a$ ), but dependent on the crown class of the sampled trees (figure $4 b$ ).

Thus, for each crown class, we can write:

$$
\frac{d v_{i}}{v_{i}}=k
$$

where $v_{i}$ and $d v_{i}$ are the volume and the annual volume increment of an elementary part of the root system respectively, and $k$ a constant. If $V$ is the volume of the whole root system of a tree, then:

$$
V=\sum v_{i}
$$

and the annual volume increment $d V$ of the whole root system is:

$$
d V=\sum d v_{i}
$$

which can be written using equations (9) and (10):

$$
d V=\sum k v_{i}=k \sum v_{i}=k V
$$

which gives:

$$
\frac{d V}{V}=k
$$

The median of the relative annual volume increments of the increment samples of each crown class was then used as an estimate of the relative annual volume increment of the whole root system of the trees of the given class, i.e.: $k=0.084$ for dominant trees, 0.067 for codominant trees, 0.051 for intermediate trees and 0.043 for suppressed trees. Approximating the wood density of all parts of the 

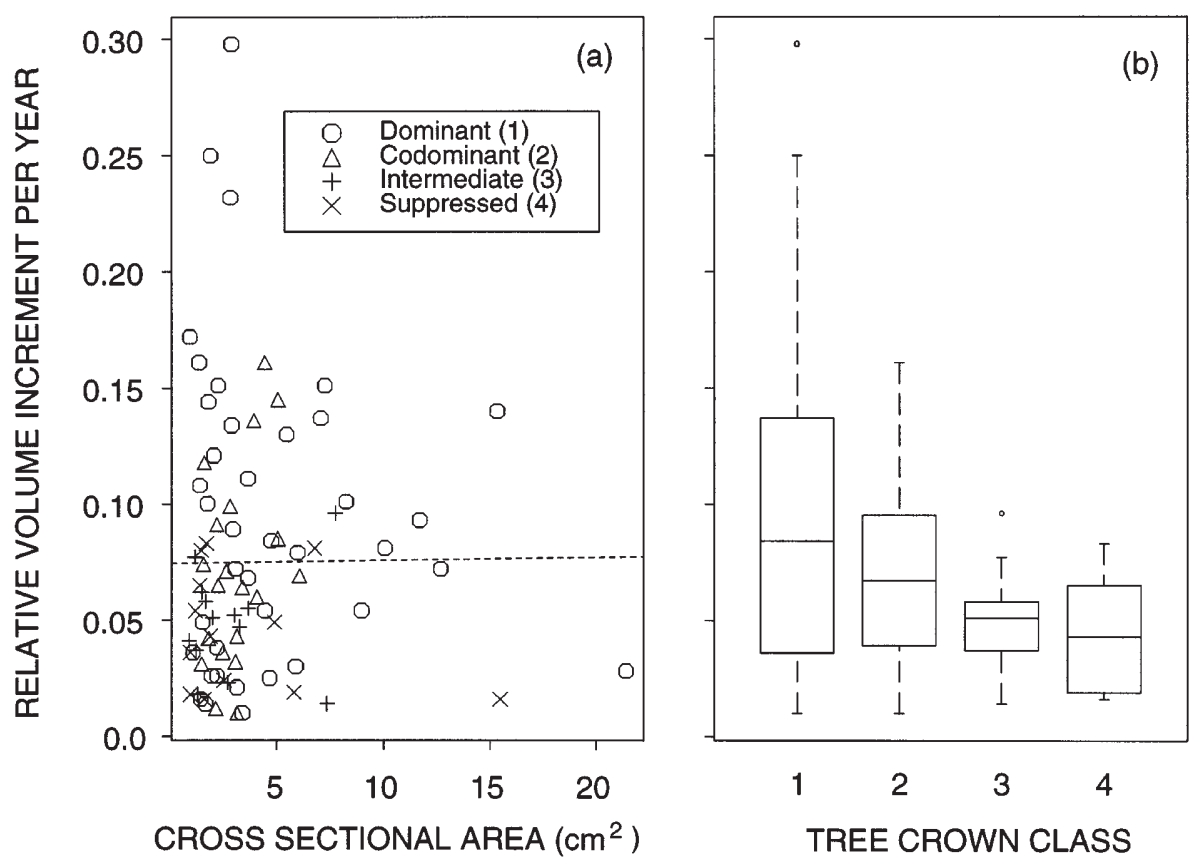

Figure 4. (a) Relative annual volume growth rate in relation to basal cross sectional area for the samples of small and coarse roots from trees of all crown classes. The regression line close to horizontal reveals the independence of both variables (b) Boxplots of the relative annual volume growth rates of the root samples for each tree crown class. The line within each box represents the median of relative annual volume increments for each crown class. Values outside the error bars (10\% to $90 \%$ of the values) are shown as individual points. Each box contains $50 \%$ of the observed values within the limits of first and third quartile.

root system by a constant value, the relative annual root biomass increment is equal to the relative annual volume increment. Thus, the annual biomass increment of the root systems of sampled trees was calculated as the product of tree root biomass (coarse and small roots) by the relative annual root biomass (volume) increment characteristic of the crown class of the trees.

Fine root production, although an important part of annual root biomass production [22] could not be obtained from root systems analyzed at a given date (time of excavation) as fine root mortality and production occur all along the year [21]. However, an estimation of fine root production could be calculated at the stand level by using an annual turnover ratio of 0.6 and using the method devised by MacClaugherty et al. [26] to estimate annual fine root production. The turnover ratio, defined here as the ratio between the production of fine roots during the growing season and the biomass of living fine roots at the end of the growing season, was derived from data obtained by Farque on the same site (unpublished data).

\subsection{Root data analysis}

\subsubsection{Biomass and biomass increment of root systems}

Relationships between tree dimensions and biomass data were investigated. DBH appeared to be the best predictor of root system biomass and biomass increment, as is commonly found for the biomass of aerial tree compartments $[2,14,16,25,32,37]$ and also for the few studies dealing with root systems $[9,30]$. Generally, linear relationships can be adjusted after a two-sided logarithmic transformation [2, 4, 30, 35]. These transformations were applied to the dependent variable (biomass and biomass increment) and to the independent variable (DBH). Apart from the linearization of the relation, the $\log$ transformation homogenized the variance of the residuals. These properties gave good conditions for adjusting the relations with the linear least squared regression method.

To obtain biomass and biomass increment estimations from the above equations, an inverse transformation was 
Table IV. Biomass and biomass increment values obtained from the analysis of the root systems of 4 sample trees in each crown class (mean, standard deviation $s d$ ) and allocated to the different root fractions (coarse roots, small roots and fine roots).

\begin{tabular}{|c|c|c|c|c|c|c|c|c|c|c|c|c|c|c|}
\hline \multirow{3}{*}{$\begin{array}{l}\text { Crown } \\
\text { class }\end{array}$} & \multicolumn{8}{|c|}{ Biomass (kg) } & \multicolumn{6}{|c|}{ Biomass increment $\left(\mathrm{kg}\right.$ year $\left.^{-1}\right)$} \\
\hline & \multicolumn{2}{|c|}{ Coarse roots } & \multicolumn{2}{|c|}{ Small roots } & \multicolumn{2}{|c|}{ Fine roots } & \multicolumn{2}{|c|}{ Total } & \multicolumn{2}{|c|}{ Coarse roots } & \multicolumn{2}{|c|}{ Small roots } & \multicolumn{2}{|c|}{ Total* } \\
\hline & Mean & $s d$ & Mean & $s d$ & Mean & $s d$ & Mean & $s d$ & Mean & $s d$ & Mean & $s d$ & Mean & $s d$ \\
\hline 1 & 18.9 & 15.7 & 1.2 & 1.0 & 1.0 & 0.7 & 21.1 & 17.3 & 1.6 & 1.3 & 0.1 & 0.1 & 1.7 & 1.4 \\
\hline 2 & 3.4 & 1.4 & 0.3 & 0.2 & 0.3 & 0.1 & 4.0 & 1.7 & 0.2 & 0.1 & 0.02 & 0.01 & 0.2 & 0.1 \\
\hline 3 & 1.6 & 0.1 & 0.18 & 0.02 & 0.16 & 0.01 & 1.9 & 0.1 & 0.08 & 0.01 & 0.009 & 0.001 & 0.09 & 0.01 \\
\hline 4 & 0.7 & 0.3 & 0.09 & 0.03 & 0.07 & 0.03 & 0.8 & 0.3 & 0.03 & 0.01 & 0.004 & 0.001 & 0.03 & 0.01 \\
\hline
\end{tabular}

* Total biomass increment does not include fine root biomass increment that could not be quantified at tree level.

applied and the values obtained were multiplied by a factor equal to the exponential of the half mean square error for bias correction [13].

\subsubsection{Extension of biomass data at stand level}

Biomass and biomass increment of roots at the stand level were calculated for years 1996 and 1997 with the equations adjusted between tree root biomass, biomass increment and $\mathrm{DBH}$, and the $\mathrm{DBH}$ inventories. The results obtained with the inventory of trees carried out in the whole experimental stand before the 1996 growing season and the results obtained with the partial inventory of the 12 sample plots realized after the growing season, were compared. Biomass and biomass increment were related to $\mathrm{DBH}$ before the growing season in the first case, and to DBH after the growing season in the second case. This comparison revealed an over-estimation of stand characteristics when the inventory was based on the 12 sample plots. The biomass and biomass increment values obtained from the partial inventory based on the 12 sample plots had to be multiplied by a correction factor of 0.8 to match the values obtained with the complete inventory. This correction factor was applied to the estimations of root biomass and biomass increment for year 1997 , as the inventory of trees was only done on the 12 subplots for that year.

\section{RESULTS}

\subsection{Tree level}

For each tree analyzed, the following data were obtained: biomass of each root category - coarse, small and fine - and total root system biomass, current annual
Table V. Regression coefficients and statistics of the root biomass and biomass increment equations which follow the form $\ln Y(\mathrm{~kg})=a+b \ln \mathrm{DBH}(\mathrm{cm})$.

\begin{tabular}{lccccc}
\hline Categories & $a$ & $b$ & se & df & $\mathrm{R}^{2}$ \\
\hline Biomass & & & & & \\
Total & -3.8219 & 2.5382 & 0.1316 & 14 & 0.99 \\
Coarse roots & -4.1302 & 2.6099 & 0.1356 & 14 & 0.99 \\
Small roots & -5.4415 & 2.0820 & 0.2284 & 14 & 0.95 \\
Fine roots & -5.7948 & 2.1609 & 0.2884 & 14 & 0.94 \\
& & & & & \\
Biomass increment & & & & & \\
Total & -7.7313 & 3.0579 & 0.1633 & 14 & 0.99 \\
Coarse roots & -7.9314 & 3.1106 & 0.1711 & 14 & 0.99 \\
Small roots & -9.1765 & 2.5528 & 0.2128 & 14 & 0.97 \\
\hline
\end{tabular}

biomass increment of coarse and small roots (table IV). The total annual biomass increments do not comprise fine root production, which was not estimated at the tree level.

\subsubsection{Biomass and biomass increment equations}

Root biomasses and root biomass increments of trees were linearly related to DBH after a two-sided logarithmic transformation (table $V$ ).

No statistical difference was found between the parameters of the above equations adjusted separately for the tree samples of years 1996 and 1997 and the parameters adjusted with the data of all the trees pooled.

\subsubsection{Biomass distribution}

The biomass and biomass increments of the different root categories - coarse, small and fine - were expressed 

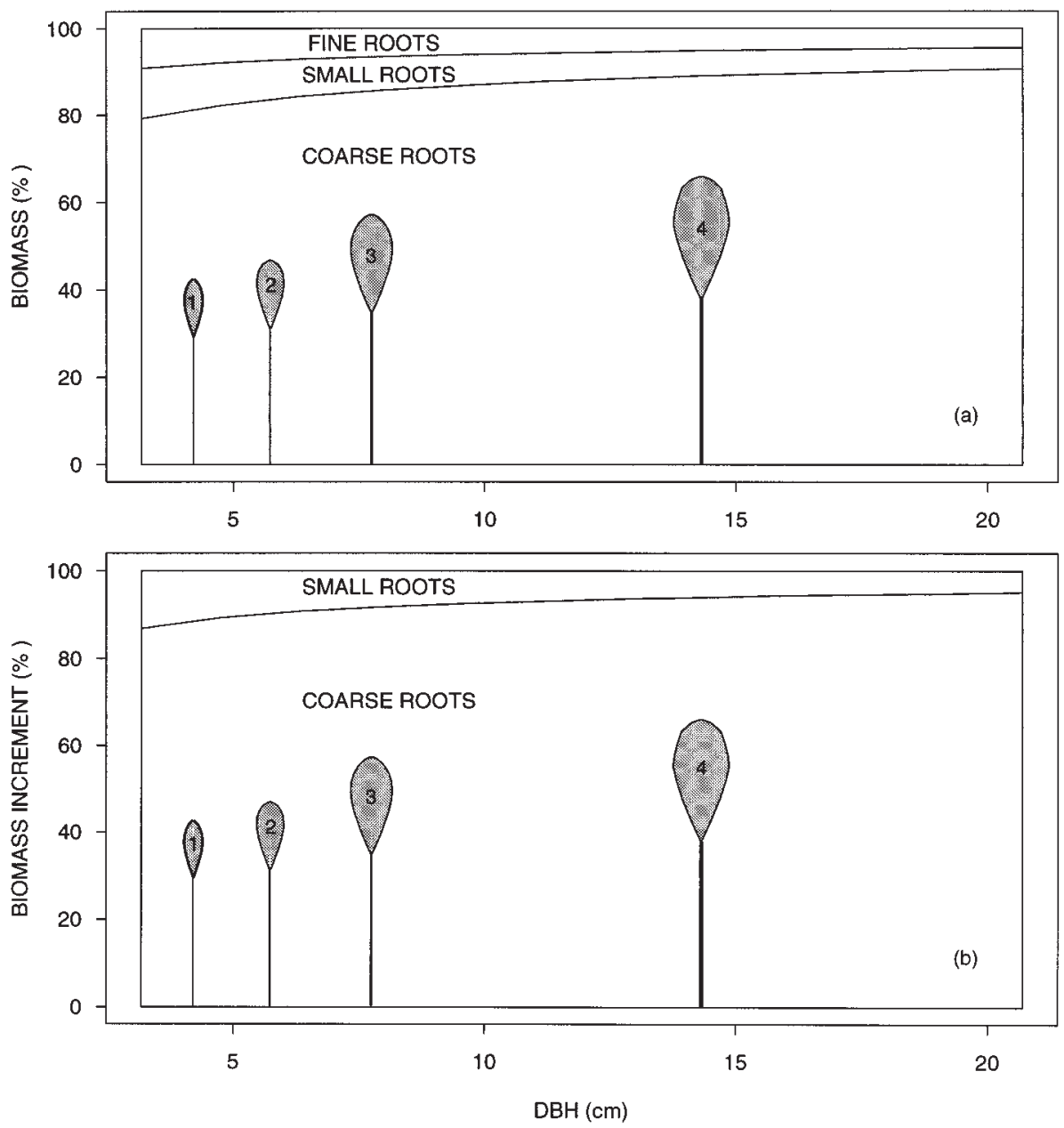

Figure 5. Contributions of the root biomass (a) and biomass increment (b) of each root category (coarse, small and fine) to the total per tree, in relation to DBH. The profiles of the mean trees of crown classes 1 to 4 (trees of diameter equal to the median of the diameters of trees in each crown class) are represented at the same scale and situated on the X-axis according to the diameter of the mean trees in each crown class. The following tree characteristics are represented: total height, height to the base of live crown, height and width of the crown at its maximum extension.

as fractions of total root system biomass in relation to DBH by using the equations established in Section 3.1.1 (figure 5).

It appears that the proportion of coarse roots - in terms of biomass - increases slightly with tree DBH and tree dominance (figure $5 \mathrm{a}$ ). On the contrary, the proportion of small and fine roots decreases with increasing $\mathrm{DBH}$ and tree dominance. The same pattern of variation was observed with biomass increments of coarse and small roots (figure $5 b$ ).

\subsection{Stand level}

\subsubsection{Biomass and biomass increment}

The stand biomass and the biomass increments of each root category and of the entire root systems were calculated for 1996 and 1997 (table VI). Coarse roots constitute the major part of the root system biomass; small root and fine root biomass each represent a similar amount. Root biomass increased from 1996 to 1997 with stand 
Table VI. Root biomass amounts and root biomass increments of the experimental beech stand in Hesse forest for 1996 and 1997.

\begin{tabular}{lrrrr}
\hline \multirow{2}{*}{$\begin{array}{l}\text { Root } \\
\text { fractions }\end{array}$} & \multicolumn{2}{c}{$\begin{array}{c}\text { Biomass } \\
(\text { ton ha }\end{array}$} & \multicolumn{2}{c}{$\begin{array}{c}\text { Biomass increment } \\
\left(\text { ton } \mathrm{ha}^{-1} \text { year }^{-1}\right)\end{array}$} \\
\cline { 2 - 5 } & 1996 & 1997 & 1996 & 1997 \\
\hline Coarse roots & 13.759 & 15.100 & 0.996 & 1.133 \\
Small roots & 1.138 & 1.209 & 0.078 & 0.086 \\
Fine roots* & 0.968 & 1.033 & 0.581 & 0.620 \\
Total & 15.863 & 17.335 & 1.655 & 1.839 \\
\hline
\end{tabular}

* Fine root biomass increment at stand level was estimated from data on fine roots dynamics obtained in the same site (see Sect. 2.5.2.).
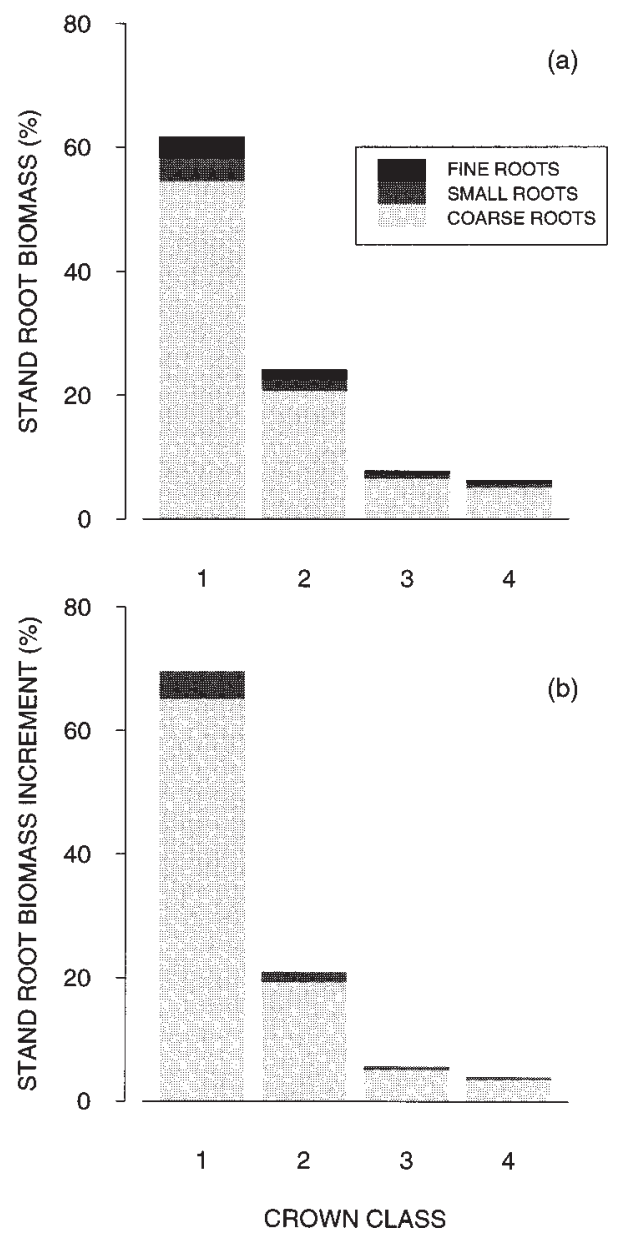

Figure 6. Contributions of root biomass (a) and of root biomass increment (b) of the trees of each crown class - dominant (1), codominant (2), intermediate (3) and suppressed (4) - to the total, at stand level. The contribution of each root category (coarse roots, small roots and fine roots) in each crown class is also represented. (Fine root biomass increment could not be represented for each crown class as it was estimated at stand level). age. The relative contribution of the different root categories to root biomass increment show the same pattern as for root biomass, except that the fine roots seem to contribute much more than the small roots to root biomass increment.

\subsubsection{Biomass distribution among crown classes}

The contribution of trees of different crown classes to the biomass and biomass increment of the stand was derived from the necessary equations and from the diameter inventory of trees with distinction of crown classes. The contribution of each crown class to root biomass and root biomass increment and the contribution of each root category in each crown class are illustrated for year 1996 (figure 6).

It appears that trees belonging to the dominant crown class contribute for about $60 \%$ to stand root biomass (figure $6 a$ ). Moreover, dominant and codominant trees contribute together to more than $80 \%$ to stand root biomass; intermediate and suppressed trees reveal then a low contribution to stand root biomass. This pattern is even emphasized for root biomass increment distribution, dominant and codominant trees contributing together to about $90 \%$ to stand biomass increment (figure $6 b$ ). The contribution of coarse roots to stand root biomass and biomass increment appears predominant in each crown class.

\section{DISCUSSION AND CONCLUSION}

\subsection{Tree root biomass and biomass increment}

The excavation of the root systems of the sampled beech trees caused the loss of some parts of the root system. However, the biomass equations established from pooled data of a sample of seemingly complete roots from several root systems allowed the estimation of the biomass of missing parts of each root system by root category. The equations established between root biomass fractions of sampled root ends and the diameter of the root ends show that coarse root biomass fraction decreases with root section diameter down to $0.5 \mathrm{~cm}$ which is the limit for coarse roots (figure $3 a$ ). Small root biomass fraction increases with root section diameter up to $0.5 \mathrm{~cm}$ (figure $3 c$ ) and then decreases at the same time as coarse roots biomass fraction increases (figure $3 b$ ). Missing parts represented a varying proportion of the measured root system biomass of trees: for $50 \%$ of trees, missing parts represented between 10 and $20 \%$ of the measured root biomass. The estimation of the biomass of missing root parts appears essential when the excavation method 
is used to extract root systems: the proportion of missing root biomass estimated is in the range of the one observed with old-growth Douglas-fir trees [30].

The treatment of pooled available data obtained from root samples taken on each sampled tree revealed the independence of root biomass increment relatively to root diameter. This allowed the estimation of root biomass increment of coarse roots and small roots of each root system by multiplying the root biomass of each root category by the mean relative root biomass increment of each crown class.

Tree DBH proved a good predictor of root biomass and root biomass increment for the different root categories and for the entire root system of beech in the conditions of the experimental stand. This is consistent with already published results on beech and other species [8, 30]. For beech, an allometric relationship between total root biomass and DBH was fitted to the data published by Pellinen [29]. For this study, taking place in Germany, a sample of 8 trees was selected in two close beech high forest stands aged 100 and 115 years old and situated on a calcareous plateau with limited soil depth (around $30 \mathrm{~cm}$ ). The root biomass estimated for the 8 sampled trees is thought to be underestimated due to the rather rough methods employed for root system extraction and to the nature of the bedrock [29]. Nevertheless, the relationship established with Pellinen's data appears reason- ably consistent with the equation established for total root system biomass in the study site of Hesse (table V and figure 7). These results suggest that individual root biomass of beech might be estimated confidently from tree DBH. Data from trees of a larger range of age classes and sites are necessary to obtain a more reliable relationship.

Tree root biomass increases with tree dimension (tables $I$ and $I V$, figure 7 ), varying from 1 to $45 \mathrm{~kg}$ in the range of sampled trees representative of the different crown classes of the experimental stand. In the same range, the root biomass increment of trees varies between 0.04 and $3.6 \mathrm{~kg} \mathrm{year}^{-1}$.

Data on root systems of beech are scarce. Figure 7, which represents the relations between total root biomass and DBH for trees of different ages (30 years old for this study and about 100 years old for Pellinen's study [29]), suggests that total root biomass is closely linked to tree dimensions and is independent of tree age, agreeing with previously published results [8].

The root biomass distribution patterns show that large trees in the stand had a higher proportion of coarse roots than smaller ones (figure 5). As dominance classes are closely linked to diameter classes, this means also that dominant trees invest relatively more biomass in coarse roots as compared to trees of lower social status. This may be related to mechanical constraints, which impose

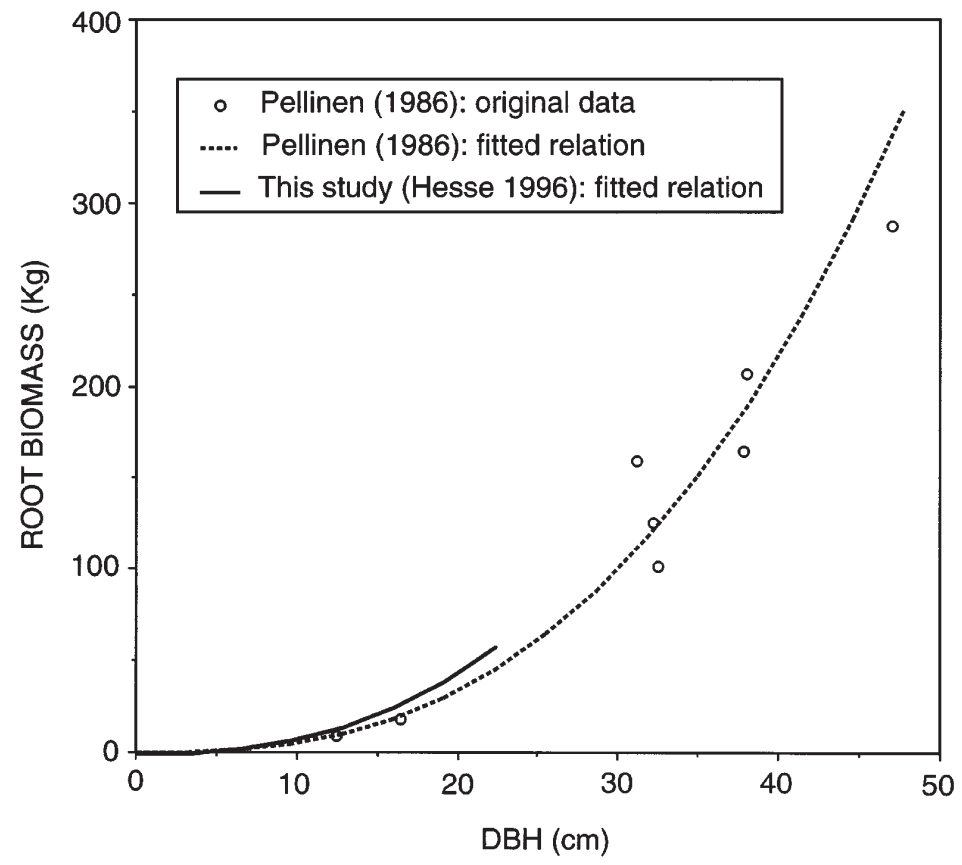

Figure 7. Comparison of the biomass equation established in this study for the whole root system of beech with the equation fitted from data of 8 trees analyzed by Pellinen [29] in Germany. 
a relatively greater development of structural roots in larger trees to ensure their stability and anchorage in the soil [34]. The decline of fine root proportion with total root biomass - or with tree DBH - was also observed by Kurz [23] from data of different studies on hardwoods and softwoods.

Fine root biomass was certainly underestimated because it is difficult to record and measure missing ends of fine roots and then obtain a corrected value of the fine root biomass measured on excavated root systems. However, this missing biomass should represent a very small part of the total root system biomass. It must also be recalled that fine root biomass may vary all along the year in relation to fine root turnover [21, 31]. However, in the study site of Hesse, the data obtained by Epron et al [12] showed that the living fine root biomass varied only slightly during the growing season.

\subsection{Stand root biomass and biomass increment}

Root biomass equations together with stand diameter distribution allowed the estimation of the total stand root biomass and biomass increment of the experimental stand. Stand root biomass reached 16 to 17 tons $\mathrm{ha}^{-1}$, whereas stand root biomass increment reached 1.6 to 1.8 tons ha $^{-1}$ year ${ }^{-1}$. Biomass data on root systems are scarce and few are available for beech stands. For stands aged between 100 and 116 years old on good productivity sites in Germany, Pellinen [29] found a root biomass of 50 to 60 tons ha ${ }^{-1}$ and a root biomass increment of 0.7 to 0.8 tons $\mathrm{ha}^{-1}$ year $^{-1}$ (excluding fine root turnover). For a beech stand aged 145 years old on a site of high productivity in Belgium, Duvigneaud and Kestemont [11] estimated a stand root biomass of 74 tons $\mathrm{ha}^{-1}$ and a root biomass increment of 1.86 tons $\mathrm{ha}^{-1}$ year $^{-1}$. Obviously, root biomass increases with stand age as it is the case for aboveground biomass [2]; root biomass variations may be due also to differences in site fertility. Root biomass increment data are relatively comparable for the different stands considered, if we estimate a fine root turnover of 0.5 to 0.6 ton ha $^{-1}$ year ${ }^{-1}$ to be added to stand root biomass increment measured in the case of Pellinen's study [29]. This means that root system biomass continues to increase at a steady rate with age, but also that the rate of increase of root system biomass decreases dramatically when the stands get older.

Stand root biomass increment in 1997 exceeded that of 1996 by $11 \%$, which may be the result of several factors: the natural rise of biomass increment with age at this stage of stand development, the probable underestimation of tree mortality from 1996 to 1997 and the better growing conditions in 1997 as compared to those of 1996. A higher net ecosystem $\mathrm{CO}_{2}$ exchange over the forest was thus observed for year 1997, probably related to a lower water stress during this year [18].

Coarse roots contribute most to total root system biomass whereas small roots and fine roots contribute very little to total root biomass. However, it appears that fine root biomass of beech stands may vary considerably from site to site and with stand age (table VII). Moreover, large differences can occur for the same site depending on the methods employed to estimate fine root biomass, as that was the case for the Hesse study site. However, with

Table VII. Fine root biomass and biomass increments in the total soil profile (except for the site of Aubure, depth of $0-40 \mathrm{~cm}$ ) for pure beech stands in different regions.

\begin{tabular}{|c|c|c|c|c|c|c|}
\hline \multirow[t]{2}{*}{ Region and source of data } & \multirow[t]{2}{*}{$\begin{array}{l}\text { Stand age } \\
\text { (years) }\end{array}$} & \multirow{2}{*}{$\begin{array}{l}\text { Upper diameter } \\
\text { limit for fine } \\
\text { roots }(\mathrm{mm})\end{array}$} & \multicolumn{2}{|c|}{ Standing root biomass } & \multicolumn{2}{|c|}{$\begin{array}{c}\text { Annual root biomass } \\
\text { increment }\end{array}$} \\
\hline & & & Method & $\left(\mathrm{g} \mathrm{m}^{-2}\right)$ & Method & $\left(\mathrm{g} \mathrm{m}^{-2}\right)$ \\
\hline Hesse (NE-France) & 30 & 2 & & & & \\
\hline -this study & & & excavation & 96.8 & soil cores & 58.1 \\
\hline -same site [12] & & & soil cores* & 800.0 & in-growth cores $* *$ & 130.0 \\
\hline \multirow[t]{2}{*}{ Veluwe (Netherlands) [19] } & 38 & 2 & soil cores & 720.0 & - & - \\
\hline & 64 & 2 & soil cores & 960.0 & - & - \\
\hline \multirow[t]{2}{*}{ Hautes Fagnes (Belgium) [36] } & 90 & 1 & soil cores & 117.8 & soil cores & 382.0 \\
\hline & & 5 & soil cores & 151.5 & soil cores & 439.0 \\
\hline Solling (Germany) [27] & 120 & 2 & soil cores & 255.2 & - & - \\
\hline Solling (Germany) [5] & 145 & 2 & soil cores & 379.0 & in-growth cores & 390.0 \\
\hline Aubure (Vosges-France) [33] & 150 & 1 & soil cores & 83.0 & soil cores & 137.0 \\
\hline
\end{tabular}

* Soil coring is performed at different sampling dates so as to evaluate an average biomass of living roots and calculate a yearly production of fine roots from the observed dynamics of live and dead roots.

** With in-growth cores, root production is measured from the recolonization of soil cores after the soil has been first cleared of pre-existing roots and replaced afterwards in its original situation. 
regards to the carbon budget, fine root production is much more important than standing fine root biomass [22]. The fine root biomass increment estimated for the experimental stand represented $1 / 3$ of the total stand root biomass increment. Nevertheless, this estimate of fine root biomass increment seems low compared to the value obtained by Epron et al. [12] in the same site with a different approach (table VII). As for standing biomass, fine root biomass increment varies widely from stand to stand, tending to increase with stand age, except perhaps for the site of Aubure, but not all the soil profile was considered in this case (table VII).

The root biomass distribution that was observed among tree crown classes, revealed the major contribution of dominant and codominant trees to stand root biomass, whichever root category was considered. Although the lower crown canopy was represented by a large number of trees in the stand - trees from crown classes 3 and 4 represent more than $50 \%$ of the total number of trees of the stand - these trees are characterized by a low annual root biomass increment and crown classes 3 and 4 represent a small proportion of stand root biomass increment. Thus, it appears that trees from these crown classes can survive in the stand but seem unable to increase their root biomass, the most part of the products from photosynthesis probably being allocated to the maintenance of the different tree compartments.

Acknowledgements: This study was supported by funds from the Office National des Forêts (O.N.F., France). The authors thank R. Canta and L. Garros ("Croissance et Production", INRA, Nancy) for technical assistance; they are also indebted to B. Clerc and F. Willm ("Écophysiologie Forestière", INRA, Nancy) for field assistance. We also wish to thank L. Farque for providing access to the data that she collected in the experimental stand studied for analyzing the dynamics of fine roots of beech. Finally, our thanks go to the two anonymous reviewers for their constructive comments and English corrections, which helped us greatly to improve the manuscript.

\section{REFERENCES}

[1] Baldocchi D., Valentini R., Running S., Oechel W., Dahlman R., Stategies for measuring and modeling carbon dioxide and water vapor fluxes over terrestrial ecosystems, Global Change Biol. 2 (1996) 159-168.

[2] Bartelink H.H., Allometric relationships for biomass and leaf area of beech (Fagus sylvatica L.), Ann. Sci. For. 54 (1997) $39-50$.

[3] Bartelink H.H., A model of dry matter partitioning in trees, Tree Physiol. 18 (1998) 91-101.
[4] Baskerville G.L., Use of logarithmic regression in the estimation of plant biomass, Can. J. For. Res. 2 (1972) 49-53.

[5] Bauhus J., Bartsch N., Fine-root growth in beech (Fagus sylvatica) forest gaps, Can. J. For. Res. 26 (1996) 2153-2159.

[6] Birdsey R.A., Methods to estimate forest carbon storage, in: Sampson R.N., Hair D. (Eds.), Forests and global change, Vol. 1: Opportunities for increasing forest cover, American Forests, Washington D.C., 1992, pp. 255-261.

[7] Cannell M.G.R., Growing trees to sequester carbon in the UK: answers to some common questions, Forestry 72 (1999) 237-247.

[8] Drexhage M., Chauvière M., Colin F., Nielsen C.N.N., Development of structural root architecture and allometry of Quercus petraea, Can. J. For. Res. 29 (1999) 600-608.

[9] Drexhage M., Colin F., Estimating root system biomass from breast-height diameters using literature derived data, Forestry (submitted).

[10] Duchaufour Ph., Pédologie 1. Pédogénèse et Classification, 2nd edn., Masson, Paris, 1983.

[11] Duvigneaud P., Kestemont P., Productivité biologique en Belgique, Duculot, Gembloux, 1977, 617 p.

[12] Epron D., Farque L., Lucot E., Badot P.M., Soil $\mathrm{CO}_{2}$ efflux in a beech forest: the contribution of root respiration, Ann. For. Sci. 56 (1999) 289-295.

[13] Flewelling J.W., Pienaar L.V., Multiplicative regression with lognormal errors, For. Sci. 27 (1981) 281-289.

[14] Gallego H.A., Santa Regina I., Rico M., Biomass equations and nutrient distribution for Quercus pyrenaica Willd. Forests, Mésogée 53 (1993) 75-82.

[15] Gholz H.L., Grier C.C., Campbell A.G., Brown A.T., Equations for estimating biomass and leaf area of plants in the Pacific Northwest, Oreg. State Univ. For. Res. Lab., Research Paper No. 41, 1979.

[16] Gower S.T., Grier C.C., Vogt D.J., Vogt K.A., Allometric relations of deciduous (Larix occidentalis) and evergreen conifers (Pinus contorta and Pseudotsuga menziesii) of the Cascade Mountains in central Washington, Can. J. For. Res. 17 (1987) 630-634.

[17] Granier A., Ceschia E., Damesin C., Dufrêne E., Epron D., Gross P., Lebaube S., Le Dantec V., Le Goff N., Lemoine D., Lucot E., Ottorini J.-M., Pontailler J.Y., Saugier B., Carbon balance of a young beech forest over a two-year experiment, Funct. Ecol. 14 (2000) 312-325.

[18] Granier A., Biron P., Lemoine D., Water balance, transpiration and canopy conductance in two beech stands, Agric. For. Meteorol. 100 (2000) 291-308.

[19] Hendricks C.M.A., Bianchi F.J.J.A., Root density and root biomass in pure and mixed forest stands of Douglas-fir and Beech, Netherlands J. Agric. Sci. 43 (1995) 321-331.

[20] Krause C., Morin H., Changes in radial increment in stems and roots of balsam fir (Abies balsamea (L.) mill.) after defoliation by spruce budworm, For. Chron. 71 (1995) $747-754$.

[21] Kurz W.A., Kimmins J.P., Analysis of some sources of error in methods used to determine fine root production in forest 
ecosystems: a simulation approach, Can. J. For. Res. 17 (1987) 909-912.

[22] Kurz W.A., Significance of shifts in carbon allocation patterns for long-term site productivity research, in: Dyck W.J., Mees C.A. (Eds.), Proceedings of IEA/BE A3 Workshop, Research strategies for long-term site productivity, Seattle, WA, August 1988, Report No. 8, Forest Research Institute, New Zealand, Bulletin 152 (1989).

[23] Kurz W.A., Beukema S.J., Apps M.J., Estimation of root biomass and dynamics for the carbon budget model of the Canadian forest sector, Can. J. For. Res. 26 (1996) 1973-1979.

[24] Lebaube S., Le Goff N., Ottorini J.-M., Granier A., Carbon balance and tree growth in a Fagus sylvatica stand, Ann. For. Sci. 57 (2000) 49-61.

[25] Leonardi S., Santa Regina I., Rapp M., Gallego H.A., Rico M., Biomass, litterfall and nutrient content in Castanea sativa coppice stands of southern Europe, Ann. Sci. For. 53 (1996) 1071-1081.

[26] MacClaugherty C.A., Aber J.D., The role of fine roots in the organic matter and nitrogen budgets of two forested ecosystems, Ecology 63 (1982) 1481-1490.

[27] Meyer F.H., Göttsche D., Distribution of root tips and tender roots of Beech, in: Integrated Experimental Ecology Methods and Results of Ecosystem Research in the German Solling Project, Springer-Verlag, Berlin, 1971, pp. 48-52.

[28] Oliver C.D., Larson B.C., Overview of stand development patterns, in: Forest stand dynamics, John Wiley \& Sons Inc., New York, 1996, pp. 145-170.

[29] Pellinen P., Biomasseuntersuchungen im Kalkbuchenwald, Dissertation Universität Göttingen, Germany, 1986, $134 \mathrm{p}$.
[30] Santantonio D., Hermann R.K., Overton W.S., Root biomass studies in forest ecosystems, Pedobiologia 17 (1977) $1-31$.

[31] Santantonio D., Hermann R.K., Standing crop, production and turnover of fine roots on dry, moderate, and wet sites of mature Douglas-fir in Western Oregon, Ann. Sci. For. 42 (1985) 113-142.

[32] Santa Regina I., Tarazona T., Calvo R., Aboveground biomass in a beech forest and a Scots pine plantation in the Sierra de la Demanda area of northern Spain, Ann. Sci. For. 54 (1997) 261-269.

[33] Stober C., Eckart G.A., Persson H., Root growth and response to nitrogen, in: Schulze E.-D. (Ed.), Carbon and nitrogen cycling in European forest Ecosystems, Ecological Studies 142 (2000) Springer-Verlag, Heidelberg.

[34] Stokes A., Guitard D., Tree root response to mechanical stress, in: Altman A., Waisel Y. (Eds.), The biology of root formation and development, Basic Life Sciences, Plenum Publishing Corporation, New York, 65 (1997) 227-236.

[35] Thies W.G., Cunningham P.G., Estimating large-root biomass from stump and breast-height diameters for Douglas-fir in Western Oregon, Can. J. For. Res. 26 (1996) 237-243.

[36] Van Praag H.J., Sougnez-Remy S., Weissen F., Carletti G., Root turnover in a beech and a spruce stand of the Belgian Ardennes, Plant and Soil 105 (1988) 87-103.

[37] Wang J.R., Zhong A.L., Simard S.W., Kimmins J.P., Aboveground biomass and nutrient accumulation in an age sequence of paper birch (Betula papyrifera) in the Interior Cedar Hemlock zone, British Columbia, For. Ecol. Manage. 83 (1996) 27-38.

To access this journal online: www.edpsciences.org 